\title{
Clinical Management of Hypophosphatemia Induced Post Parturient Hemoglobinuria in a Buffalo
}

\author{
R.S. Kathiravan ${ }^{1 *}$ and G. Shanmuga Priya ${ }^{2}$ \\ ${ }^{1}$ Farm Manager, Directorate of Centre for Animal Health Studies, \\ TANUVAS, Chennai- 600051, India \\ ${ }^{2}$ Veterinarian, Centre for Laboratory Animal Technology and Research, Sathyabama Institute \\ of Science and Technology, Shollinganallur, Chennai-600119, India \\ *Corresponding author
}

A B S T R A C T

\section{Keywords \\ Hemoglobinuria , Hypophosphatemia, Hemolysis \\ Article Info \\ Accepted: \\ 22 June 2020 \\ Available Online: \\ 10 July 2020}

\section{Introduction}

Chronic phosphorus deficiency is commonly caused by inadequate feed intake or inadequate phosphorus content in the ration over an extended time and also in grazing animals in arid regions with low phosphorus content in soil. The sudden onset of phosphorus losses through the mammary gland at the onset of lactation and the decreased feed intake around parturition are believed to be the major contributors to postparturient hypophosphatemia of dairy buffalo (Cohrs and Grünberg, 2018). Hypophosphatemia in dairy buffalo is thought to be associated with an increased risk of disease and impaired productivity particularly in early lactation. Postparturient haemoglobinuria (PPHb) is a clinical syndrome of bovines characterized by intravascular haemolysis, haemoglobinuria and anemia (Bhat, 2010; Mac Williams et al., 1982). The condition is commonly noticed in third to sixth lactation of dairy animals (Radostitis et al., 2000) during the period from calving to fifth week of postpartum (MacWilliams et al., 1982). The etiology of $\mathrm{PPHb}$ is believed to involve hypophosphataemia associated to primary dietary deficiency (Chugh et al., 1998; 
Samad, 1997). The present case report explains the diagnosis and successful treatment of PPHb in a 6 year old buffalo.

\section{History}

A 6 Years old female buffalo weighing around $300 \mathrm{Kg}$ was presented in Thangam Memorial Trust Hospital, Tirupur with the condition of coffee colored urine, partial feeding for past three days, reduced milk yield from 3.5 lit to 1.5 lit and calved one month back. The same episode was reported during last calving and treated by local veterinarian.

\section{Diagnosis}

On clinical examination, the buffalo had high temperature $39.8^{\circ} \mathrm{C}$, hemoglobinuria (Fig. 1), swollen lymph nodes, tachycardia, pale mucous membrane, polypnea-38/minute, high pulse rate-78/min and doughy rumen with reduced motility. Urine sample was tested positive for glucose and bile salts and the supernatant remains in dark red color on centrifugation. Blood sample had reduced Hemoglobin-4.5g/dl, PCV-16\%,RBC$2.5 \times 10^{6} \mathrm{ml}$. The serum biochemistry reveals hypophosphatemia- $1.9 \mathrm{mg} / \mathrm{dl}$ and negative for hemoprotozoa.

\section{Treatment}

The animal was treated with Inj. Oxytetracycline - $60 \mathrm{ml}$, Inj. Normal saline $1000 \mathrm{ml}$ intravenously, Inj. Zobid-M - $10 \mathrm{ml}$ and Inj. Tribivet $-10 \mathrm{ml}$ intramuscularly in first day.

Treatment repeated for 4 days along with Inj. Alphos - $20 \mathrm{ml}$, Calcium borogluconate - 450 $\mathrm{ml}$ and Inj. Ringers lactate - $1000 \mathrm{ml}$ intravenously, Inj. Iron sorbital (Feritas) - 6 $\mathrm{ml}$ intra muscularly and bolus. Styphon - 8 boli (2-0-2). Clinical status of the animal improved on $5^{\text {th }}$ day of treatment with improved serum phosphorus level of $4 \mathrm{mg} / \mathrm{dl}$, Hemoglobin - 7.1g/dl, PCV - 26\%, RBC $4.5 \times 10^{6} \mathrm{ml}$ and urine colored changed to light yellow.

Fig.1 Clinical symptom of hemoglobinuria in buffalo

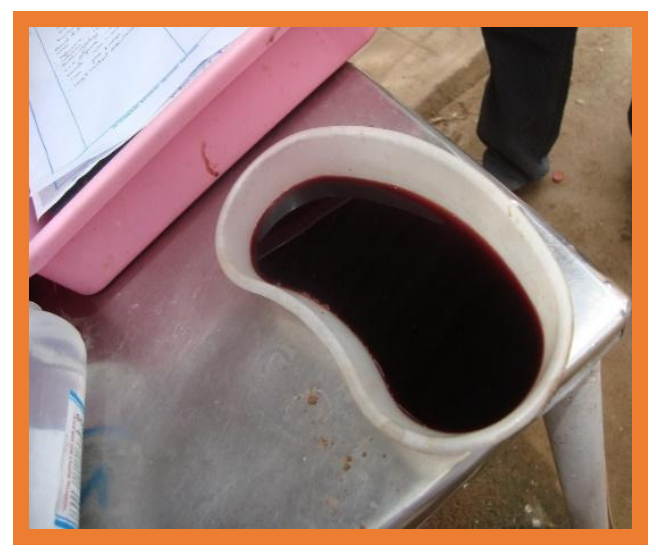

Acute phosphorus losses associated with hypophosphatemia are a well-recognized problem in high-yielding dairy cows at the onset of lactation. Phosphorus depletion can also result from chronic renal tubular disease due to impaired renal reabsorption of phosphorus.

Chugh et al., (1998) reported the severe hypophosphataemia leads to post-parturient 
haemoglobinuria in buffaloes. The initial serum phosphorus level in the present reported case was $1.8 \mathrm{mg} / \mathrm{dL}$. This is lower than the normal range $(2 \mathrm{mg} / \mathrm{dL})$ indicating phosphorus deficiency in bovines (Samad, 1997).

Increased fragility associated with hypophosphatemia is suggested to subject erythrocytes to destruction by circulating oxidants (Jubb et al., 1990). Phosphorus deficiency is usually primary i.e. involving an absolute deficiency in the diet (Radostitis et al., 2000).

Symptoms includes pale mucous membrane, anemia, increased heart rate ,increased pulse rate, dyspnea, difficult in defecation, hemoglobinuria, decreased serum phosphorus. Young animals grow slowly, develop rickets, and tend to have a rough hair coat, whereas adult animals in early stages may become lethargic, anorectic, and lose weight (MSD vet manual). The phosphorus deficiency, leading to hypophosphatemia, may be a mechanism of post parturient and related syndromes of haemoglobinuria by decreasing red cell glycolysis and resultant ATP synthesis. Subnormal concentrations of ATP would predispose red cells to altered structure and function, a loss of normal deformability, and an increase in fragility and haemolysis with resultant haemoglobinuria (Ogawa et al., 1987) Chronic phosphorus depletion and hypophosphatemia is most effectively treated by providing sufficient amounts of feed with adequate phosphorus content. Intravenous administration of phosphorus-containing solutions is the most appropriate approach. In cattle, rapid administration of sodium phosphate salt solutions is commonly practiced. Mono or dibasic phosphate salts (either $\mathrm{Na}_{2} \mathrm{HPO}_{4}$ or $\mathrm{NaH}_{2} \mathrm{PO}_{4}$ ) infused IV rapidly increase the serum $\mathrm{Pi}$ concentration. Tribasic phosphate $\left(\mathrm{Na}_{3} \mathrm{PO}_{4}\right)$ is a caustic detergent that cannot be used under any circumstances for PO or IV phosphorus supplementation. (MSD vet manual).

In conclusion a single injection of acid sodium phosphate $20 \mathrm{ml}$ intravenous route is giving correction for acute hyphophataemia in Buffaloes. The treatment has a rapid onset of action and a sustained effect. Severe hyphophosphataemia condition is an indicator for intravenous rather than oral phosphorus supplementation. Prevention of hyphophosphataemia is the best therapy. So these treatments should be used only if indicated and carefully monitored.

\section{References}

Bhat, P.N. 2010. Buffalo Production. Studium Press (India) Pvt. Ltd, 302- 304 Chugh, S.K., R.M. Bhardwaj and M.M. Mata. 1998. Lowered antioxidant status of red blood cells in post-parturient haemoglobinuria of buffaloes. Vet. Res. Commun., 6: 383-388.

Chugh, S.K., R.M. Bhardwaj and M.M. Mata. 1998. Lowered antioxidant status of red blood cells in post-parturient haemoglobinuria of buffaloes. Vet. Res. Commun., 6: 383-388.

Cohrs, I. and Grünberg, W. 2018. Suitability of oral administration of monosodium phosphate, disodium phosphate, and magnesium phosphate for the rapid correction of hypophosphatemia in cattle. J Vet Intern Med. 32(3):12531258.

Mac Williams P.S., G.P. Searcy and J.E.C. Bellamy. 1982. Bovine post-parturient haemoglobinuria. Canadian Veterinary Journal, 23: 309.

MSD vet manual.2014.Walter Gruenberg, MedVet, DECAR, DECBHM, University of Veterinary Medicine Hannover, Foundation. Apr 2014.

Ogawa., Kobayashi, K., Yoshiura, N. and Mukai, J. 1987. Bovine Postparturient 
Hemoglobinemia: Hypophosphatemia and Metabolic Disorder in Red blood cells. Am. J. Vet. Res. 48; 1300-3.

Radostits, O. M., C.C. Gay, K. W. Hinchcliff and P. D. Constable. 2000. VETERINARY MEDICINEA; textbook of the diseases of cattle, horses, sheep, pigs and goats. Saunders Elsevier, Edinburgh London New York Oxford Philadelphia St Louis Sydney Toronto, $1700-1793 p$.
Samad, A. 1997. Host and environmental factors associated withphosphorus deficiency hemaoglobinurea in buffaloes. Buffalo j, 13: $385-395$.

Wang, X.L., C.H. Gallagher, T.J. McClure, V.E. Reeve and P.J. Canfield. 1985. Bovine postparturient haemoglobinuria: effect of inorganic phosphate on red cell metabolism. Res Vet Sci, 39(3): 333339.

\section{How to cite this article:}

Kathiravan, R.S. and Shanmuga Priya, G. 2020. Clinical Management of Hypophosphatemia Induced Post Parturient Hemoglobinuria in a Buffalo. Int.J.Curr.Microbiol.App.Sci. 9(07): 3132-3135. doi: https://doi.org/10.20546/ijcmas.2020.907.368 